\title{
A new methodology for modelling of health risk from urban flooding exemplified by cholera \\ Case Dhaka, Bangladesh
}

Mark, Ole; Jørgensen, Claus; Hammond, Michael; Khan, David; Tjener, Ronni; Erichsen, Anders; Helwigh, Birgitte

Published in:

Journal of Flood Risk Management

Link to article, DOI:

10.1111/jfr3.12182

Publication date:

2018

Document Version

Peer reviewed version

Link back to DTU Orbit

Citation $(A P A)$ :

Mark, O., Jørgensen, C., Hammond, M., Khan, D., Tjener, R., Erichsen, A., \& Helwigh, B. (2018). A new methodology for modelling of health risk from urban flooding exemplified by cholera: Case Dhaka, Bangladesh. Journal of Flood Risk Management, 11(51), S28-S42. https://doi.org/10.1111/jfr3.12182

\section{General rights}

Copyright and moral rights for the publications made accessible in the public portal are retained by the authors and/or other copyright owners and it is a condition of accessing publications that users recognise and abide by the legal requirements associated with these rights.

- Users may download and print one copy of any publication from the public portal for the purpose of private study or research.

- You may not further distribute the material or use it for any profit-making activity or commercial gain

- You may freely distribute the URL identifying the publication in the public portal 
A new methodology for modelling of health risk from urban flooding exemplified by cholera

\author{
- Case Dhaka, Bangladesh
}

Ole Mark*(corresponding author), Claus Jørgensen*, Michael Hammond**, David Khan***; Ronni

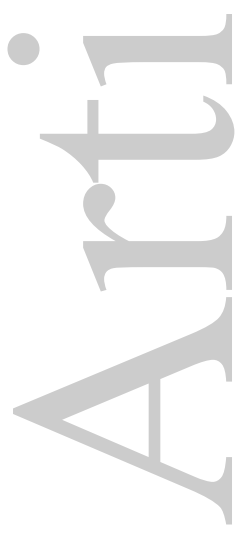

Tjener*; Anders Erichsen*; Birgitte Helwigh****

* DHI, Agern Allé 5, Hørsholm, 2970, Denmark

** University of Exeter, Exeter, United Kingdom

***Institute for Water Modelling, Dhaka, Bangladesh

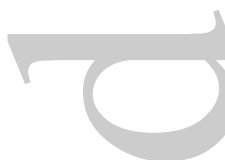

****The Technical University of Denmark, Denmark

(E-mail: Ole.Mark@dhigroup.com)

This article has been accepted for publication and undergone full peer review but has not been through the copyediting, typesetting, pagination and proofreading process, which may lead to differences between this version and the Version of Record. Please cite this article as doi: 10.1111/jfr3.12182

This article is protected by copyright. All rights reserved. 
Abstract

The phenomenon of urban flooding due to rainfall exceeding the design capacity of drainage systems is a global problem and can have significant economic and social consequences. This is even more extreme in developing countries, where poor sanitation still causes a high infectious disease burden and mortality, especially during floods. At present, there are no software tools capable of combining hydrodynamic modelling and health risk analyses, and the links between urban flooding and the health risk for the population due to direct contact with the flood water are poorly understood. The present paper outlines a novel methodology for linking dynamic urban flood modelling with quantitative microbial risk assessment (QMRA). This provides a unique possibility for understanding the interaction between urban flooding and health risk caused by direct human contact with the flood water and hence gives an option for reducing the burden of disease in the population by use of intelligent urban flood risk management. The model linking urban flooding and health risk is applied to Dhaka City in Bangladesh, where waterborne diseases including cholera are endemic. The application to Dhaka City is supported by measurements of pathogens in the urban drainage system. The outcome of the application indicates that direct contact with polluted flood water is a plausible route of primary transmission of cholera and demonstrates the applicability and the potential for linking urban flood models with QMRA in order to identify interventions to reduce the burden of disease on the population in Dhaka City.

Keywords: Dhaka, health risk, QMRA, sewer modelling, urban drainage, urban flooding, wastewater

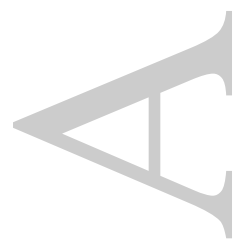

This article is protected by copyright. All rights reserved. 


\section{Introduction}

Cholera is an important infectious diarrhoeal disease with high human and economic impacts. It is estimated that 2.8 million cases occur annually in endemic countries (with a lethal outcome for 91,000, while 1.4 billion people are at risk) and 87,000 cases occur in non-endemic countries with a lethal outcome for 2,500 (Ali 2012). The infections influence the population as such, but the incidence is estimated to be higher for children under 5 years of age (Ali 2012, Deen 2008, Sur 2005).

Cholera is caused by an infection of the human intestine by the bacterium Vibrio cholerae after ingestion of contaminated water (Ramamurthy and Sharma, 2014) or foods (FAO, 2005, Rabbani, 1999). V. cholerae is a naturally occurring (autochthonous) bacterium in estuarine and brackish environments, where it is found as a free-living organism or associated with plankton and sediments, and it has shown also to have the ability to colonize freshwater ecosystems (Alam et al 2006, Colwell 2005, Borroto 1997, Huq 1990). V. cholera occurs at elevated temperatures, typically above $19{ }^{\circ} \mathrm{C}$ (Louis et al., 2003), and shows an optimum growth between $30{ }^{\circ} \mathrm{C}$ and $37{ }^{\circ} \mathrm{C}$ (Borroto 1997). V. cholerae has an absolute requirement for $\mathrm{NaCl}$, with optimal salinities between 2 and 25 parts per thousand (Louis et al., 2003, Borroto, 1997). Therefore, the aquatic environment plays a significant role in cholera epidemics and serves as a reservoir between outbreaks (Alam et al 2011).

Cholera is endemic to Bangladesh (Lipp et al. 2002). Sporadic cases of cholera occur every year and epidemics reoccur regularly (Longini et al., 2002). The entire population in Bangladesh is considered to be at risk of contracting cholera, and the overall annual incidence rate is estimated to be around 4 per 1000 (Ali, 2012). The magnitude of the epidemics may be driven by climatic factors such as the El Niño southern oscillation and sea surface temperatures (Koelle et al. 2005, Reiner et al. 2012). In the Dhaka area, Reiner et al. (2012) found a correlation between El Niño, flooding and cholera epidemics, 
particularly in the core areas of the city. Moreover, an analysis of 33 years of cholera in rural Bangladesh found that a small spring outbreak occurs around April, and there is a clear annual outbreak in September through December (Longini et al. 2002). Dhaka also experiences biannual outbreaks. The spring peak can be explained by intrusion of salt water into the Bengal Delta which, combined with high temperatures, gives favorable conditions for $V$. cholerae and subsequently an increased risk of infection (Akanda et al. 2009, 2011, 2013). A similar situation was observed in the Indus river basin where cholera risk is correlated to above average temperatures followed by above average rain (Jutla et al. 2013). The fall peak in the Bengal Delta was found to be correlated with high flow in the Ganges-BrahmaputraMeghna basin and with the flooding extend (Akanda et al. 2013), and large outbreaks in Dhaka have shown to be correlated with the floods of 1988, 1998, 2004 (Schwartz et al. 2006) and 2007 (Alam, 2011, Hashizume et al. 2008). The studies by Akanda and co-workers (2013), however, do not directly represent a causal connection but identify two plausible physical variables in the transmission process.

Cholera outbreaks have been suggested to follow two routes of transmission. A primary transmission from environmental exposure followed by a secondary direct or indirect person to person transmission, where the indirect secondary transmission includes fecal contaminated water, which may involve the same aquatic reservoirs as those of the primary transmission (Miller et al. 1985, Ruiz-Moreno et al., 2010). We hypothesize that the fall cholera outbreak in Dhaka is mainly related to a primary infection via the urban flood water caused by autochthonous Vibrio cholera. In addition, cholera cases may also be due to infections from drinking water contaminated with flood water, or from an indirect secondary infection via the faecal oral route by exposure to flood water or contaminated drinking water.

This article is protected by copyright. All rights reserved. 
The 2007 outbreak in Dhaka was caused by a hyper infective clone, V. cholerae $01 \mathrm{El}$ Tor, which is believed to have a yearly cycle mediated via the aquatic environment and during the outbreak transmitted via the faecal-oral route (Alam et al. 2011). Faeces from cholera patients typically contain $10^{7}$ to $10^{8}$ V. cholerae per. g (Dizon et al. 1967 , Levine et al. 1988). Hence, it only takes a relatively small number of seriously ill patients to contaminate the sewage and drainage systems in Dhaka and lead to secondary infections via contamination of drinking water or via direct contact with the mixture of surface and drainage water during flooding.

Infectious waterborne diarrhoeal diseases are generally found to be related to low socioeconomic status, poor drinking water quality and sanitation, and cholera is no exception. Hashizume et al. (2008) observed a significantly higher cholera risk in the post-flood period for those using tube wells for drinking water compared with those using tap water. However, Colombara (2013) failed to show an association between cholera risk and water and sanitation variables among children in Dhaka, but found that social economic status, age and maternal education were key correlates of cholera risk. In India, most outbreaks are believed to be associated with inadequate water supply. However, cholera has also been linked with washing of clothes and bathing in the Ganges (Ramamurthy and Sharma, 2014). In addition, despite the successful effort of providing improved drinking water and the improvements in sanitation in developing countries (WHO 2013), there has been little evidence of a decline in the global burden of disease of cholera (Ali 2011). Hence, exposure to other waters than drinking water may also be important routes of transmission of $V$. cholera. Interventions against cholera must intersect all principal routes of transmission (not only via drinking water) to be effective.

In this paper we analyze the primary infection from the direct human exposure to drainage and flood water based on hydraulic modelling of the 2004 floods in Dhaka and provide a first quantitative microbial assessment of cholera risk during flooding to better understand the relationship between 
flooding and cholera risk in Dhaka, to provide the basis for more effective evidence-based interventions and to develop better tools for forecasting epidemics.

\section{Description of the setting in Dhaka City}

Dhaka, the capital of Bangladesh, is one of the most densely populated cities in the world. The average population density in the central part of the city is approximately 47,600 per $\mathrm{km}^{2}$. Greater Dhaka is bounded by the Balu River on the east, the Tongi Khal on the north, the Turag Rivers on the west and the Buriganga River on the south. The western part of Greater Dhaka is flood protected whereas the eastern part is unprotected. In recent years, Dhaka has experienced a rapid urbanization and the development of urban infrastructure. Combined with urban flooding this has created an environment which can be detrimental to millions of people.

There are two kinds of floods in Dhaka city: fluvial flooding and water logging. Fluvial flooding is caused by high river levels, which overtop the banks of Balu River in the east. Water logging is mainly caused by heavy rainfall which exceeds the drainage capacity. The floods of 1954, 1955, 1968, 1971, 1974, 1987, 1988, 1998 and 2004 were the most disastrous floods in Dhaka City. During the 2004 flood, $40 \%$ of the city and its habitants suffered directly due to water logging. Approximately 176,000 families and around 900,000 people were affected. Sometimes river flooding and the water logging occur simultaneously,

e.g. when high river stages at drain outfalls cause backwater effects in the drainage system leading to water logging. During every monsoon season, large portions of Dhaka city are inundated due to its lowlying and flat topography. In 1998, around 56\% of Dhaka was inundated for about 69 days, including most of the unprotected eastern part.

Dhaka's urban drainage system is a mixture of a partly separate wastewater and storm water system and a combined system. Even in areas where there is provision of separate sewers, much of the This article is protected by copyright. All rights reserved. 
wastewater discharges through the storm water drainage system. Most of the sewerage infrastructure within Dhaka is ineffective due to either blocked or damaged sections, leading to environmental degradation and unhygienic conditions. Due to rapid urbanization the city is experiencing massive construction works and as a result run-off carries a large amount of sediment which clogs the drainage system.

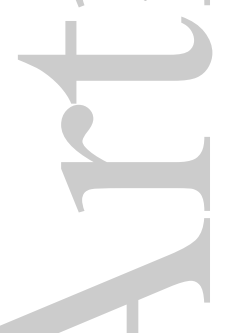

\section{Methodology}

Hydrodynamic and advection-dispersion urban flood models, which describe the transport of pollutants and water flow in the urban drainage system and on the surface, were used to determine the concentrations of pollutants in the surface flood waters (Hartnack et al., 2009). I.e. the drainage model was applied to estimate the quality of the mixture of wastewater and storm water spilled from the urban drainage system to the surface during flooding. Several important mechanisms have been modelled. First, the transport and dilution of wastewater and storm water in the drainage system is modelled using a 1-D hydrodynamic model, which can incorporate advection-dispersion processes (Garsdal et al. 1995). Hence, $V$. cholerae is transported in the system as a conservative pollutant, which is justifiable as the time frame for the transport is short compared to the die-off rate. Secondly, when the capacity of the drainage system is exceeded, the diluted sewerage spills into the surface flood waters, and this behavior is shown by a hydrodynamic 2-D flow model, which can also incorporate advection-dispersion processes. The models compute the water depth, flow velocity and concentrations of pollutants as a function of time for all spatial points in the model domain. Decay or growth of $V$. cholerae was not taken into account due to the relatively short duration of the flooding under 
consideration. A quantitative microbial risk assessment (QMRA) was undertaken to estimate the risk of illness caused by infection by $V$. cholerae $\mathrm{O} 1 \mathrm{El}$ Tor via direct human contact with flood water.

\section{Modelling of urban flooding}

The flood model for Central Dhaka was developed using DHI MIKE Urban (Andersen et al, 2004). The model covers an area of $39.2 \mathrm{~km}^{2}$ and includes 852 sub-catchments. The rainfall-runoff process is simulated by a time-area model. The percentage of impervious surface area was calculated at $39 \%$. The model comprises all important drainage system elements, i.e. both storm sewer pipes and box culverts.

The total length of the network is $112 \mathrm{~km}$. There are three sluice gates/regulators and two pump stations in the model to represent the pumps in Rampura and Shegunbagicha. There are three large lakes within the central part which act as detention ponds during storm events.

The urban drainage network in the model was described by use of a MIKE FLOOD, a 1D hydrodynamic model, while the surface flow is computed using a 2D model (Hartnack et al. 2009). The 2D model reproduces the urban surface topography, allowing for the hydrodynamic simulation of surface flood water. This flood simulation approach is commonly used for urban flood studies (Schmitt et al. 2004; Carr and Smith 2007; Mark and Djordjevic 2006) and is available in software packages such as INFOWORKS (Rubinato et al., 2013; Innovyze 2013) and MIKE FLOOD (Hartnack et al. 2009). The accuracy of these 2D flood models depends on the accuracy and resolution of the digital terrain model and its links with the 1D urban drainage model. The recommended grid size for urban 2D surface models is usually $1-5 \mathrm{~m}$ (Mark et al. 2004). In the current research, a grid size of $10 \mathrm{~m}$ was used, as a sensitivity analysis showed that this reproduces the topography of the city and the flooded areas while still giving acceptable run times for the simulations. In order to support this, the flood model was calibrated both

for water levels in the urban rivers and for the flood extent of the 2004 flood. For the calibration of the 
flood extent, a flood map of historically observed flooded locations was produced by The Institute of Water and Flood Management. The observed flood map is consequently a schematic map based on field investigations. For the calibration, the flood extent was matched with the flood map drawn upon the observations.

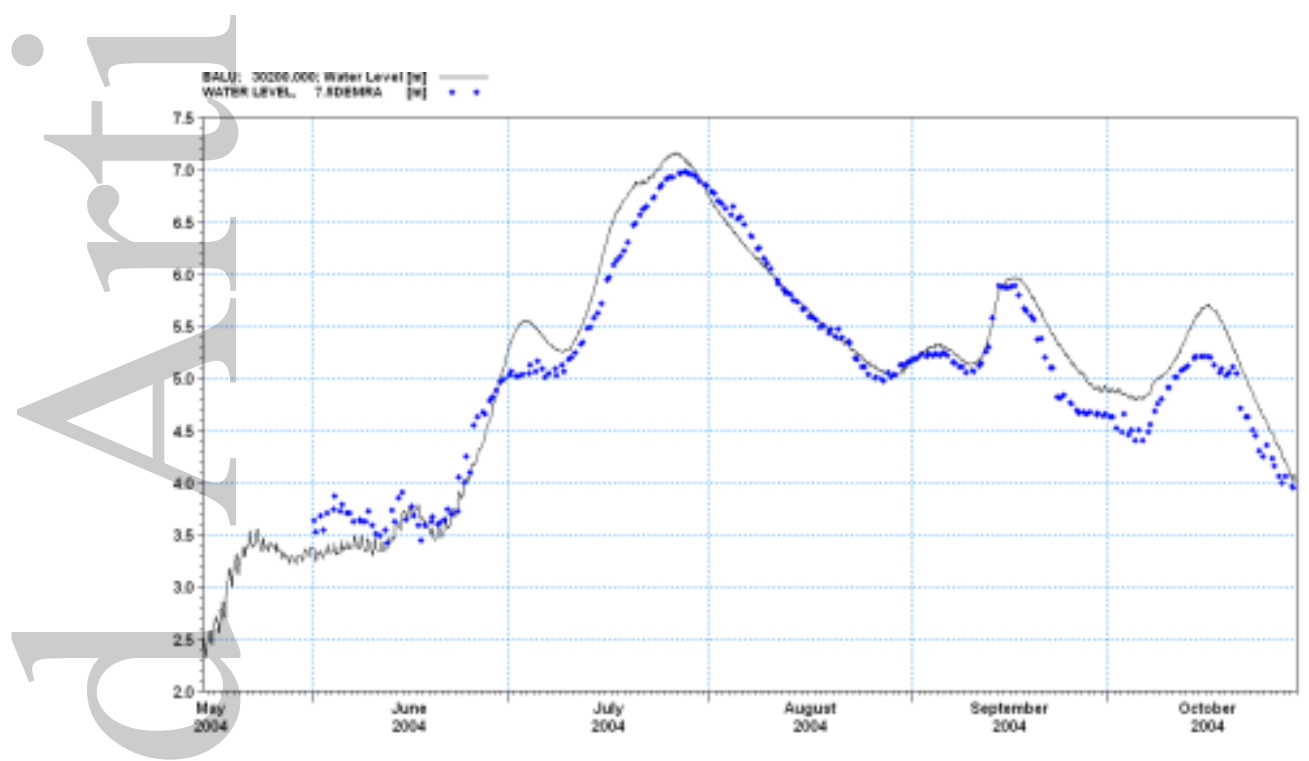

Figure 1 Model calibration at Demra on the Balu River

The calibration results can be seen in Figure 1, where the observed and simulated maximum flood extents are shown for the storm in September 2004. For simulation of the health risk, two days with urban flood were selected for the analysis. In total, the model was run for three days in order to capture both the rising and the falling limb of the flooding. 


\section{Modelling of concentration in urban flood water}

The simulation of the pathogens and their transport in the urban drainage system and on the surface was carried out using a 1D advection-dispersion model (MOUSE TRAP) (Garsdal et al. 1995) of the urban drainage system, which was coupled with a 2D advection-dispersion model (MIKE 21) (Hartnack et al. 2009). The 1D advection-dispersion models have previously been applied to cases for simulation of the transport and dilution of wastewater (Mark et al. 1996; Mark et al. 1998; Andersen et al. 2013).

The $2 \mathrm{D}$ advection-dispersion model solves the mass-conservative advection-dispersion equation for dissolved substances in two dimensions:

$\frac{\partial}{\partial t}(h c)+\frac{\partial}{\partial x}(u h c)+\frac{\partial}{\partial y}(v h c)=\frac{\partial}{\partial x}\left(h \cdot D_{x} \cdot \frac{\partial c}{\partial x}\right)+\frac{\partial}{\partial y}\left(h \cdot D_{y} \frac{\partial c}{\partial y}\right)$

Where

c : compound concentration (arbitrary units)

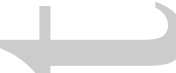

$u, v$ : horizontal velocity components in the $x, y$ directions $(\mathrm{m} / \mathrm{s})$

$\mathrm{h}$ : water depth $(\mathrm{m})$

$D_{x}, D_{y}$ : dispersion coefficients in the $x, y$ directions $\left(\mathrm{m}^{2} / \mathrm{s}\right)$

Information on $\mathrm{u}, \mathrm{v}$ and $\mathrm{h}$ at each time step is provided by the hydrodynamic module. 


\section{Cholera risk assessment}

Hazard identification and dose-response relations

Epidemic Vibrio cholerae has two major serogroups (01 and 0139). The 01 serogroup has two biotypes (classical and El Tor), and each biotype has two major serotypes (Ogawa and Inaba). Since 1993, the El

Tor V. cholerae $\mathrm{O} 1$ and V. cholerae $\mathrm{O} 139$ have been the dominant biotypes in Bangladesh (Longini et al. 2002). In 2004, V. cholerae $O 1$ was the dominant serogroup (ICDDR,B 2004). Therefore, the EI Tor V. cholerae $\mathrm{O} 1$ was selected as the reference pathogen for cholera risk modelling. Only one study (Bui et al. 2011) has examined the dose-response relationship for El Tor $V$. cholerae $O 1$ Inaba. The best fit model for illness $\left(P_{\text {ill }}\right)$ was the approximated beta-poison relation:

$P_{\text {in }}(c V ; \alpha, \beta)=1-\left(1+\frac{c V}{\beta}\right)^{-\alpha}$

Where $c=$ concentration of $V$. choler $a$ and $V$ is the volume ingested and with $\alpha=0.169$ and $\beta=2,305$ $\left(N_{50}=137\right)$.

The $D / R$ is based on data from Levine and co-workers (Black et al. 1987, Levine et al., 1981 and 1988). Approximately 60 fasting volunteers, who were students and other healthy adults from Maryland, USA, were administered $V$. cholera (Doses: $10^{3}$ to $10^{6}$ ) with $2 \mathrm{~g}$ of $\mathrm{NaHCO}_{3}$. The $\mathrm{NaHCO}_{2}$ increases infectivity and pathogenicity by lowering the acidity as a standard meal of fish, rice; custard and skim milk does (Levine et al. 1981). The analytical methods for determining the doses in the D/R study and in our study should ideally be equivalent. The method used in the D/R studies originates from Cash et al. (1974) and 
was based on culture techniques. We have also used culture techniques. We therefore assume that the methods are comparable.

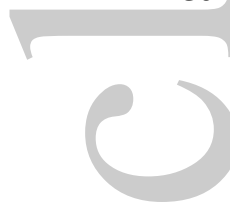

Quantification of human exposure to flood water

Here we estimate the risk from exposure to flood water by direct ingestion and hand to mouth exposure. During the field study in Dhaka (12 Nov. to 15 Nov. 2013) 26 individuals and a group of children were interviewed about their behavior during floods. Information was collected on the age of the participants and the frequency and duration of water contact via direct ingestion and hand to mouth contact. The social status of the interviewees was estimated by questioning, from their appearance and from their place of living. Slum areas (e.g. Koreil, UTM, WGS84 N23 46.971, E90 24.704) and areas with mixed middle class/poor inhabitants (e.g. Rajabagh N23 44.559, E90 25.092) were visited. In general, the exposure was related to social status and age. The small children (under approximately 5 years) in the slum areas were the most exposed group and the upper middle class adults the least exposed.

The interviews revealed the following results:

1. Small children ( $<5$ years) in slum areas are in contact with the flood water throughout the day.

2. Adults in slum areas and poor areas wade through or remain in the water from one to several hours either because of the need to get to and from work or by remaining in the flooded area.

3. Children (> 5 years) in poor areas and slum areas are exposed during trips to school and often play in the water: e.g. running, playing soccer, cricket and even water polo.

4. Street vendors may stay in the flood water for extended periods and are exposed to contaminated water through hand contact and splashing from vehicles. 
5. Middle class and upper middle-class adults try to avoid contact either by staying home during a flood or by being transported by car or rickshaw. Most say they get wet hands.

6. Middle class and upper middle-class children usually have restricted access to the flood water by the parents but may be exposed going to and from school.

The literature reveals different approaches to the quantification of oral intake during contact with water. Scheets et al. (2011) examined the amount of water swallowed, and the frequency and duration of swimming events (freshwater, seawater and in swimming pools) in the Netherlands by questionnaires. They found that on average children ingested $37 \mathrm{ml}$ during 79 minutes of bathing in freshwater. Dorevitch et al. (2011) examined the ingestion during water recreation in swimming pools by analyzing cyanuric acid uptake by the participants. 23 adults were studied in shallow swimming pools ("splash pools"), and they found a mean ingestion of $3.5 \mathrm{ml}$ (median $2 \mathrm{ml}$ ) with an upper confidence (95\%) limit of $10.6 \mathrm{ml}$ during 60 minutes activity. Exposure data during flooding in the Netherlands was collected via questionnaires by de Man et al. (2014). The study revealed that children swallowed $1.7 \mathrm{ml}$ (mean, 95\% Confidence Interval $0-4.6 \mathrm{ml}$ ) per flood exposure event and adults ingested $0.016 \mathrm{ml}$ (mean, 95\% Cl $0-0.068 \mathrm{ml}$ ) due to hand-mouth contact during flooding events. Based on the field interviews above, we have selected 4 typical exposure groups for the assessment of the cholera risk. The exposure groups and their expected exposure to flood water are shown in Table 1, and an example of the probability density function (PDF) for the volume ingested can be seen in Figure 2. Thus, PDFs are developed for the exposure groups and applied as inputs to the QMRA modelling.

Table 1 Exposure groups for which the cholera risk has been estimated and models for quantification of exposure to flood water.

\begin{tabular}{|l|l|l|l|}
\hline Group & Exposure description & Exposure/day & Reference \\
\hline
\end{tabular}

This article is protected by copyright. All rights reserved. 


\begin{tabular}{|c|c|c|c|}
\hline $\begin{array}{l}\text { Small children in the } \\
\text { slum and poor areas }\end{array}$ & $\begin{array}{l}\text { The children stay partly emerged } \\
\text { in the water for several hours. } \\
\text { Considered exposed as children in } \\
\text { recreational water }\end{array}$ & $\begin{array}{l}37 \mathrm{ml} \\
\text { Gamma distribution } \\
r=0.64, \lambda=58\end{array}$ & Scheets et al. 2011 \\
\hline $\begin{array}{l}\text { Adults in slum and in } \\
\text { poor areas }\end{array}$ & $\begin{array}{l}\text { Wading one hour/day on the way } \\
\text { to work or another business. }\end{array}$ & $\begin{array}{l}\text { Lognormal } \\
\mu=3.5 \mathrm{ml} \\
\sigma=3,6 \mathrm{ml}\end{array}$ & Dorevitch et al. 2011 \\
\hline $\begin{array}{l}\text { Middle class/upper } \\
\text { middle-class children }\end{array}$ & $\begin{array}{l}\text { Exposed on the way to school } \\
\text { etc., but exposure usually } \\
\text { restricted by parents. }\end{array}$ & $\begin{array}{l}\text { Mean: } 1.7 \mathrm{ml} \\
95 \% \mathrm{Cl}: 0-4.6\end{array}$ & 'de Man et al. 2014 \\
\hline $\begin{array}{l}\text { Middle class/upper } \\
\text { middle-class adults }\end{array}$ & $\begin{array}{l}\text { Avoid exposure but exposed via } \\
\text { hands }\end{array}$ & $\begin{array}{l}\text { Mean: } 0.016 \mathrm{ml} \\
95 \% \mathrm{Cl} 0-0.068\end{array}$ & *de Man et al. 2014 \\
\hline \multicolumn{4}{|c|}{$\begin{array}{l}\text { The set of 100,000 exposure volumes underlying the assessment by de Man et al. (2014) of the infection risk fron } \\
\text { exposure to waterborne pathogens in urban floodwater was used for the Monte Carlo simulation. The data set } \\
\text { was kindly provided by Dr. Heleen de Man, Institute for Risk Assessment Sciences, Utrecht University, the } \\
\text { Netherlands. }\end{array}$} \\
\hline
\end{tabular}

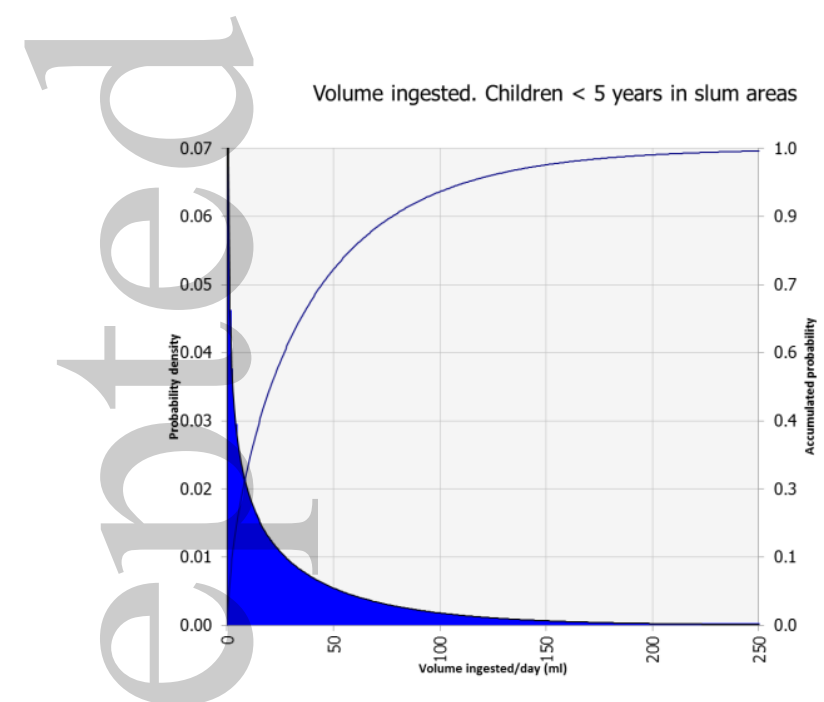

Figure 2 The probability density function is describing the volume ingested by children $(<5$ years) living in poor areas of Dhaka. This PDF is applied as input to the QMRA modelling.

\section{Sampling and microbial analyses}


Information on water quality was obtained through a sampling programme. The samples for this study were taken by the Institute of Water Modelling, Dhaka, Bangladesh from three locations in Dhaka

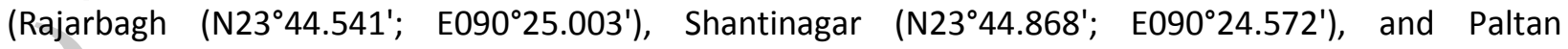
$\left.\left(\mathrm{N} 23^{\circ} 44.157^{\prime} ; \mathrm{E}^{\circ} \mathrm{O}^{\circ} 24.930^{\prime}\right)\right)$. Seven wet weather samples were taken hourly (11.00 to 17.00$)$ from the flood water on 8 September 2013 and 7 dry weather flow samples (every 4 hours from 10 am to 10 am) were taken from the drainage system on 15/16 September 2013.

$500 \mathrm{ml}$ water samples were aseptically collected in sterile Nalgene plastic bottles following APHA procedures (APHA, 1998). The samples were placed in an insulated box with ice packs and immediately transported to the Environmental Microbiology Laboratory of the International Centre for Diarrhoeal Disease Research, Bangladesh (ICDDR,B) for analysis.

The samples were analyzed for Enterococci, E. coli, V. cholerae and V. cholerae O1 El Tor (Inaba and Ogawa).

For the analysis of $E$. coli, $5 \mathrm{ml}$ water samples from three different dilutions were analyzed by membrane filtration (APHA 1998, Islam et al. 2011). Enterococci were analyzed according to ISO 7899-2:2000. V. cholerae and $V$. cholerae $01 \mathrm{El}$ Tor were quantified by a $3 \times 3 \mathrm{MPN}$ procedure. $1,0.1$ or $0.01 \mathrm{ml}$ of sample were inoculated into $10 \mathrm{ml}$ alkaline peptone water and sub-cultured. Following overnight incubation colonies were subjected to further characterization to determine if they were $V$. cholerae according to Hara-Kudo et al. (2001) and Islam et al. $(1995,2011)$. V. cholerae strains were then serotyped according to the method described by Kelly et al. (1992) to identify V. cholerae 01 El Tor, Inaba or Ogawa.

Quantitative Microbial Risk Assessment

This article is protected by copyright. All rights reserved. 
A quantitative microbial risk assessment (QMRA) was performed by Monte Carlo simulation (@Risk, Palisade, Industrial Edition; Version 6.0.1) using Latin Hypercube sampling and 40.000 iterations. The dosages were sampled from a Poisson distribution with an average calculated from the measured concentration in the dry weather samples, with the dilution of the drainage water sampled for the entire duration of modelled time series shown in Table 2, and the ingested volume sampled from distributions presented in Table 1, assuming a maximum exposure time of one day. The risks were then calculated for the four exposure groups shown in Table 1.

Risk assessment locations

Three areas in Dhaka with known flood occurrences were selected a priori for the risk assessment. The locations are either close to the sampling sites or chosen on the basis of the field interviews. The locations are: a slum area approximately 200 m east of the Bir Shreshtha Mostafa Kamal Stadium

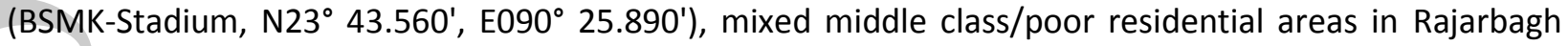
$\left(\mathrm{N} 23^{\circ} 44.559^{\prime}, \mathrm{E} 090^{\circ} 25.092^{\prime}\right)$ and Paltan (N2344.208', E090 $\left.24.710^{\prime}\right)$ near the sampling sites.

\section{Results}

\section{Urban sewer model results}

A model was prepared using SewerGems to analyze the performance of the existing sewer system. The sewer model was developed using information from engineering plans. Much of the sewer system was 
not functioning properly, so it was difficult to determine the extent of sewer connections from these plans. In order to address this uncertainty in the existing system, scenarios were set up considering the sewer system to be connected to $20 \%, 65 \%$ and $100 \%$ of the service area respectively. Figure 3 shows the overflow from sewer manholes if $65 \%$ of the population is connected to the sewer system in order to represent the condition of 2004.

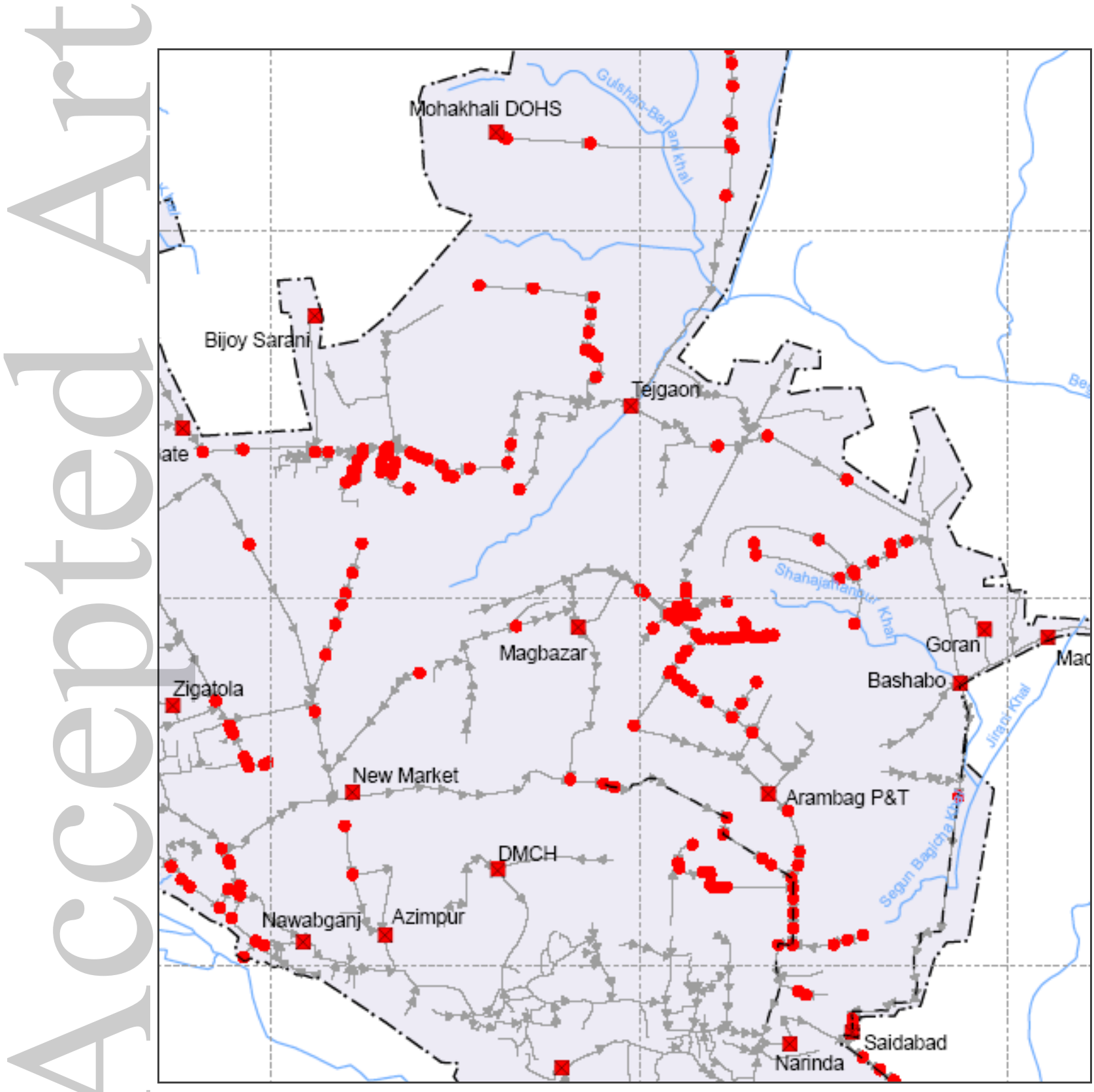


Figure 3 Flood Manholes with 65\% connection rate
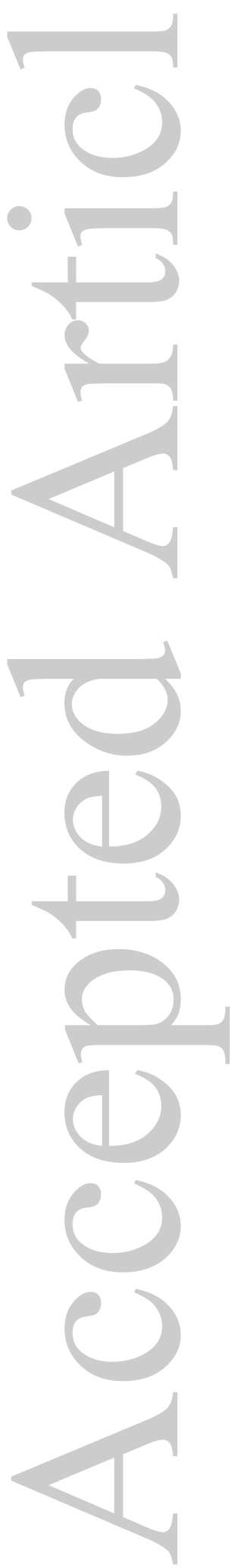

This article is protected by copyright. All rights reserved. 


\section{Flood model results}

The central part of Dhaka is protected from flooding by an embankment. The storm water is then evacuated using pumps at the outlets. There are also large detention ponds which can store water during storm events. A 1D-2D coupled model was developed based on the existing drainage network and digital elevation model (DEM) of the city. During September 2004, a major flood occurred which inundated a large part of the city for several days. The observed inundation is shown in Figure 4, and the model simulated inundation maps are shown in Figure 5. It can be seen that there is a good agreement between the observed and simulated flood locations. It would have been useful if also flood depths had been recorded to provide a better basis for the calibration of the flood model, but unfortunately observed flood depths are not available.

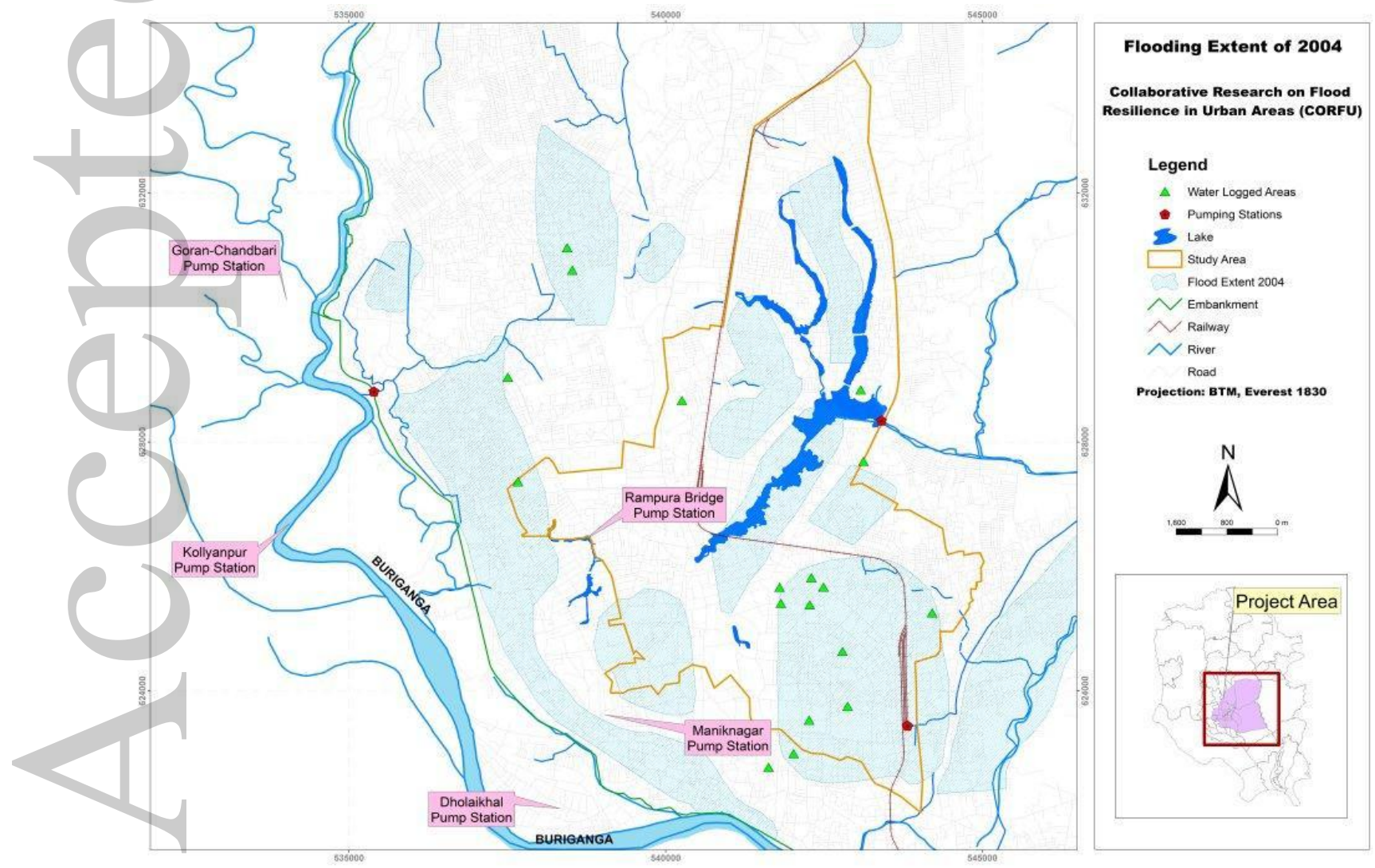

This article is protected by copyright. All rights reserved. 
Figure 4 Observed flooding for the September 2004 flood. The observed locations of the flood are indicated by the light blue shaded color. The green triangles indicate water logged areas.

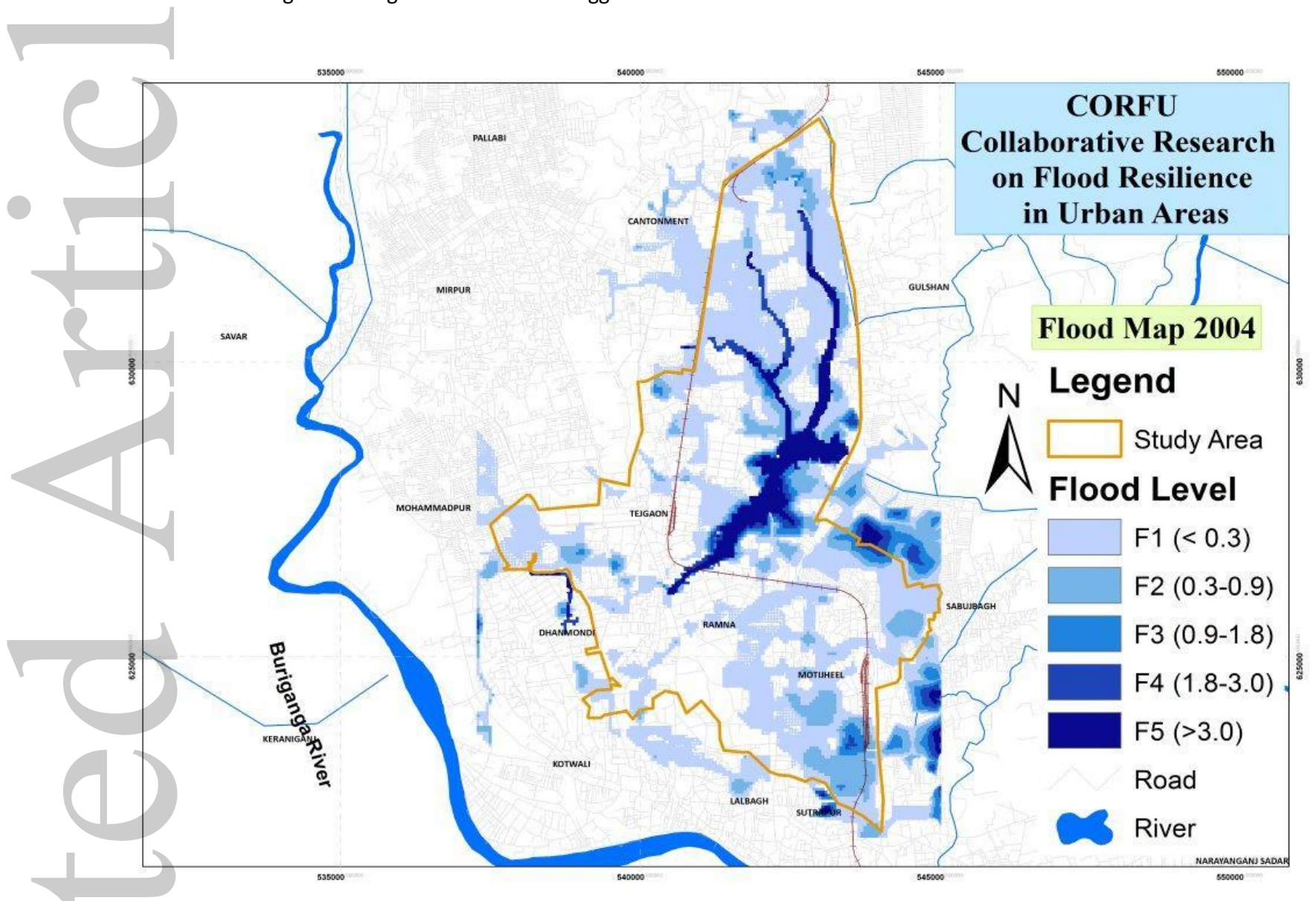

Figure 5 Model simulated flooding of September 2004

In addition to the simulation of the flood extent, the transport and dilution of the sewage water transported on the surface were simulated by use of the $2 \mathrm{D}$ advection-dispersion model. I.e. the concentrations in the urban flood water come from the concentrations in the dry weather flow, which are mixed and transported in the rain and surface runoff. The model results are shown in Figure 6 , and they display the maximum concentrations (dilution) of sewage in the flood water on the surface of Dhaka City. 


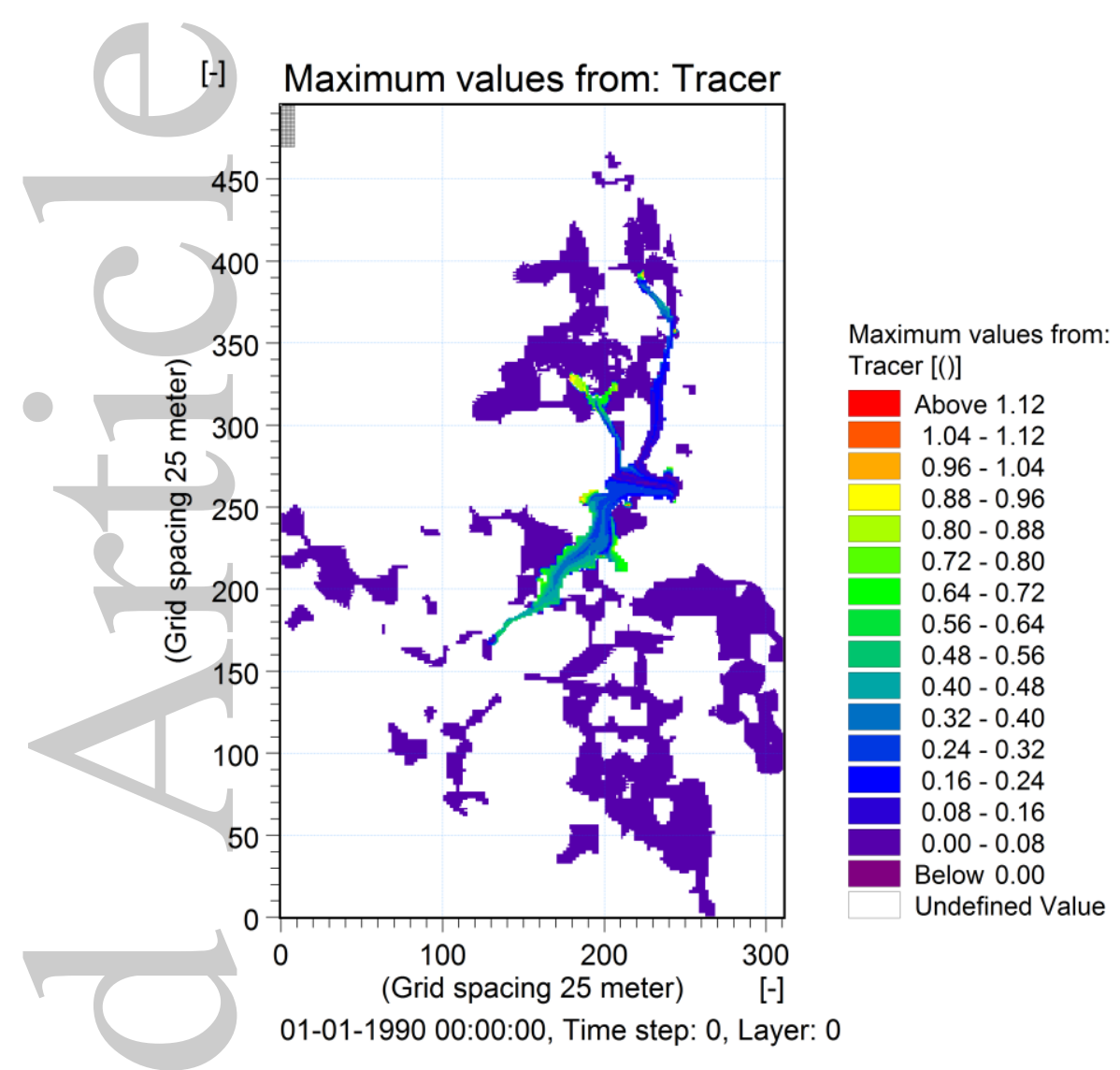

Figure 6 The pollution map computed for the flood in September 2004. The map shows the dilution factor of wastewater in the flood water. The concentration is represented as a dilution factor of the wastewater concentration.

The health risk was subsequently computed for the three selected locations as shown in Table 2. In Table 2 it can be observed that the mean event dilution ranges from $1.1210^{-3}$ to $5.8310^{-3}$ for the locations, where the risk assessments are carried out. However, it should be noted that locations with a dilution factor in the order of 0.75 show a large spatial variation due to the mixing with the dry weather flow and the transport of the flood water.

Table 2 Model results of the drainage water dilution at the three risk assessment locations 


\begin{tabular}{|l|l|l|l|l|l|l|}
\hline & \multicolumn{2}{l|}{ Rajarbag } & \multicolumn{2}{l|}{ BSMK-Stadium } & \multicolumn{2}{l|}{ Paltan } \\
\hline Flood duration (hours) & 23 & 7 & 9 & \multicolumn{2}{l|}{} \\
\hline & Dilution factor & Depth $(\mathrm{m})$ & Dilution factor & Depth $(\mathrm{m})$ & Dilution factor & Depth $(\mathrm{m})$ \\
\hline Maximum & 0,009576 & 0.14 & 0,00755 & 0.19 & 0,00227 & 0.45 \\
\hline Minimum & 0,000225 & 0.45 & 0,00328 & 0.55 & 0,00077 & 0.74 \\
\hline Average & 0,002275 & 0.30 & 0,00583 & 0.35 & 0,00112 & 0.50 \\
\hline
\end{tabular}

\section{Results of the microbial analyses}

The results of the microbial analyses are shown in Table 3.

Table 3 Enterococci, E. coli, V. cholerae and V. cholerae $\mathrm{O} 1 \mathrm{El}$ Tor in samples from wet weather and dry weather periods.

\begin{tabular}{|l|l|l|l|}
\hline $\begin{array}{l}/ 100 \mathrm{ml} \\
\text { Geometric mean and one } \\
\text { standard deviation }\end{array}$ & E. coli & Enterococci & V. cholerae \\
\hline Wet weather & $10^{6.8 \pm 0.7}$ & $10^{5.9 \pm 0.2}$ & $10^{3.8 \pm 0.8}$ \\
\hline Rajarbagh & $10^{7.2 \pm 0.2}$ & $10^{5.9 \pm 0.1}$ & $10^{4.0 \pm 1.0}$ \\
\hline BSMK-Stadium & $10^{7.5 \pm 0.6}$ & $10^{6.1 \pm 0.1}$ & $10^{4.0 \pm 0.9}$ \\
\hline Paltan & \multicolumn{1}{|l}{} \\
\hline Dry weather flow & $10^{7.5 \pm 0.5}$ & $10^{6.2 \pm 0.2}$ & $10^{4.1 \pm 0.8}$ \\
\hline Rajarbagh & $10^{7.7 \pm 0.5}$ & $10^{6.0 \pm 0.1}$ & $10^{4.3 \pm 0.5}$ \\
\hline BSMK-Stadium & $10^{7.7 \pm 0.6}$ & $10^{6.1 \pm 0.2}$ & $10^{4.2 \pm 0.8}$ \\
\hline Paltan & & & \\
\hline
\end{tabular}

The concentrations of $E$ coli and Enterococci ranged from $10^{6}$ to $10^{8}$ per $100 \mathrm{ml}$, which is typical for raw sewage (Feachem et al., 1983). The concentration of non-01, $0139 \mathrm{~V}$. cholera ranged from $10^{3}$ to $10^{5}$ per. $100 \mathrm{ml}$. Taking both weather flow and wet weather results into account, it was found that on 
average the concentration of E. coli was $1.4 \log$ units higher than the concentration of Enterococci and $3.4 \log$ units higher than the concentration of non 01, $0139 \mathrm{~V}$. cholera. The concentrations were higher ( $13 \%$ to $49 \%$ on average) under dry weather conditions compared to wet weather conditions. No trends were observed in the temporal variation seen over the individual sampling days.

V. cholerae $\mathrm{O} 1 \mathrm{El}$ Tor, Ogawa was found in two samples (300 and 300 per. $100 \mathrm{ml}$ ) in Paltan and in one sample in Razarbag (360 pr. $100 \mathrm{ml}$ ) under dry weather flow conditions. The detection limit of the $3 \times 3$ MPN-setup was 300 per $100 \mathrm{ml}$. We have used the average dry weather flow concentration of $V$. cholerae $01 \mathrm{El}$ Tor (46 V. cholerae $01 \mathrm{El} \mathrm{Tor} / 100 \mathrm{ml}$ ) for the risk assessment.

\section{Health modelling results}

The averages and $95^{\text {th }}$ percentiles of cholera risk are shown in Table 4. The highest estimated risk is 5.6 . $10^{-3}$ per day of flooding for children in the Paltan slum area and the lowest risk is $10^{-6}$ or lower for the middle-class adults. The 5-percentiles, the median risks and most of the 95 percentiles were all below the detection limit of the simulation, due to sampling from a Poisson distributed dose, where most events result in zero ingestion.

Children have a higher average risk than adults. For the middle class in Razarbag, the childrens' risk is about 70 times higher than the adult risk. In the poor/slum areas the childrens' risk is about 10 times higher than the adults' risk. The population in the slum/poor areas has higher risks than the middle class. For the children, the average risk is 109 times higher in Paltan and 19 times higher in Razarbag. For adults the average risk is 145 times higher in Razarbag and higher in Paltan, where the adult risk was undetectable for the middle class.

This article is protected by copyright. All rights reserved. 
Table 4 Estimated daily average and 95 percentiles health risk at the time of the lowest modeled dilutions (i.e. highest concentration of $V$. cholerae) at the three model locations for the four selected exposure groups. All 5 percentiles and medians were 0.

\begin{tabular}{|l|l|l|l|l|}
\hline Location and Dilution factor & \multicolumn{4}{|l|}{ Estimated cholera risk during the highest modelled concentrations } \\
\hline & \multicolumn{2}{|l|}{ Children } & \multicolumn{2}{l|}{ Adults } \\
\hline & Average & $\mathbf{9 5}$ percentile & Average & 95 percentile \\
\hline Razarbag & & & & \\
\hline Slum/Poor & $2.2 \cdot 10^{-3}$ & 0 & $2.1 \cdot 10^{-4}$ & 0 \\
\hline MiddleClass & $1.2 \cdot 10^{-4}$ & 0 & $1.5 \cdot 10^{-6}$ & 0 \\
\hline Paltan & & & & \\
\hline Slum/Poor & $5,6 \cdot 10^{-3}$ & 0,059 & $5.5 \cdot 10^{-4}$ & 0 \\
\hline Middle Class & $5.2 \cdot 10^{-5}$ & 0 & 0 & 0 \\
\hline East of BSMK-Stadium & & & 0 & \\
\hline Slum/Poor & $1.1 \cdot 10^{-3}$ & 0 & $1.1 \cdot 10^{-4}$ & 0 \\
\hline *Middle Class & $2.6 \cdot 10^{-4}$ & 0 & $3.1 \cdot 10^{-6}$ & 0 \\
\hline *No middle class in this area & & & \\
\hline
\end{tabular}

\section{Discussion}

In this work, an urban flood model, which represents the observed flood in Dhaka in 2004, has been applied to compute the concentrations of sewage and V. cholerae O1 El Tor in the flood water. This was used as input to a QRMA model, which estimated the risk of cholera caused by contact with flood water during the 2004 flood event. Hence, the estimation of the health risk is based on a calculation of the dilution of drainage/sewage water at three locations in Dhaka. The average risks were estimated to be in the range between below "detection limit" of the Monte Carlo simulation and 5.6 $\cdot 10^{-3}$. Typical average values were $10^{-3}$ for children and $10^{-4}$ for adults in poor/slum areas and $10^{-5}$ for children and $10^{-6}$ for adults in middle-class areas. The results are well in accordance with the overall incidence of severe cholera in Dhaka City, which was estimated to be approximately 280 per 100,000 in 2010 (ICDDR, B This article is protected by copyright. All rights reserved. 
2011). However, direct comparison between the calculated risks due to direct exposure to flood water and the estimated incidence would require an analysis of the population distribution and risk assessment in all the flooded areas. Deen et al. (2008) report an annual incidence of culture-positive cholera cases in cholera endemic slum areas in Kolkata, India and Jakarta, Indonesia to be 7.0/1000 and $2.0 / 1000$ respectively for the small children ( $<5$ years) and $1.2 / 1000$ and $0.27 / 1000$ respectively for children ( $\geq 5$ years). Hence, our risk estimates seem to be in a realistic range.

A number of factors influence the uncertainty of the risk estimation. The water ingestion was determined by transferring exposure data obtained from studies in Europe and North America to Dhaka. This was based on the findings of our field studies, which indicate similar behaviors in the identified exposure groups in Dhaka and in the studies cited above. We do not know with certainty if the estimated ingested volumes are correct; however, the field study clearly showed that children in the slum areas are without any doubt highly exposed, whereas middle-class adults have a lower exposure. The dose-response relation used was based on healthy adult volunteers in North America. The populations in Dhaka may be more vulnerable due to generally poorer health status or may have higher immunity than adult North Americans, since having had cholera reduces the risk of subsequently becoming ill (Ali 2012),. We have used the only published dose response relation for V. cholerae O1 El Tor. It has a low infectious dose and may be seen as a worst case. For comparison, the classical $V$. cholera usually appears less infective and requires higher doses for infection, i.e. $N_{50}$ in the $10^{3}-10^{9}$ range, where the high $\mathrm{N}_{50}$ was found in studies without administration of $\mathrm{NaHCO}_{3}$ (Hass et al. 1999, CAMRA 2014). We detected V. cholerae O1 El Tor Ogawa in the wastewater, whereas the dose-response relation was determined for $V$. cholerae $01 \mathrm{El}$ Tor Inaba. However, the attack rates of Inaba and Ogawa biotypes seem not to be significantly different (Levine et al., 1984). The calculated risks are based on 3 samples out of 21 with concentrations corresponding to the detection limit of the method. A sensitivity 
analysis showed close to linearity between concentration and risk at the used concentration. Errors in the estimation of the concentration will therefore influence the risk estimate. A more thorough field investigation of the spatial and temporal variation of the environmental concentrations will reduce the uncertainty related to the concentration and improve the risk estimations. Hence, the absolute risk estimates determined in this study should be interpreted with caution. They are, however, in accordance with observed incidences, and the geographical distribution can be used to identify high-risk locations. Finally, it must be mentioned that the present analyses are just carried out for one flood event in 2004. In order to get a more comprehensive picture of the health risk, it is recommended that the mean annual burden of disease is computed similarly to the computations of the mean annual flood damage. However, this is outside the scope of the present paper.

Our risk model indicates that the direct contact with drainage and flood water may be a significant route of primary cholera transmission, particularly in poor/slum areas. However, we cannot estimate the contribution of direct exposure to flood water to the total cholera disease burden. Other microbial risk studies have also identified the environmental exposure as an important route of transmission in slum areas. Labite et al (2010) analyzed the burden of waterborne (non-cholera) infectious disease in a slum area in Accra, Ghana and found that open drains and recreational activities accounted for $90 \%$ of the burden of disease, whereas ingestion of flood water ( $1 \mathrm{ml} / \mathrm{year}$ ) accounted for $2 \%$ of the burden of disease, and the drinking water-related disease burden accounted for $6 \%$ of the disease burden. Similarly, a study from Bwaise III, an urban slum in Kampala, Uganda (Katukiza et al., 2013) found that open drainage canals and grey water in tertiary drains accounted for $63 \%$ of the disease burden, whereas the drinking water-related exposure accounted for $30 \%$ of the disease burden. Because $V$. cholera is a naturally occurring bacterium, the environmental compartment may be even more important for the primary transmission than what is the case for non-naturally occurring pathogens.

This article is protected by copyright. All rights reserved. 
Schwartz et al. (2006) found that the cholera epidemics in Dhaka are related to the flood levels, with a delay of 3 to 13 days after the rivers have reached the flood stage. The risk model presented here suggests that the direct ingestion of flood water should be considered as a plausible causal link between flooding and cholera risk.

The relation between the estimated risks associated with the different exposure groups depends on the authors' choice of the exposure models. The exposure models were chosen based on behavioral interviews with inhabitants of flood risk areas. We estimated the child/adult relation of cholera risk in slum areas to be 10. It is well known that the children under 5 years of age bear the highest burden of cholera. In Kolkata and Jakarta the child-adult cholera incidence ratios are 5.9 and 7.4 respectively (Deen et al., 2008), which is not significantly different from our results. Exposure via drinking water is probably more or less the same for children and adults, since they can be expected to use the same water source, and is therefore not a plausible explanation of the differences between adults and children. Children are in closer contact with the environmental sources than adults because they are playing, running, swimming, etc. Environmental exposure is therefore a more likely explanation for the differences between adults and children. However, a lower adult cholera risk is not only caused by lower ingested doses. Having had cholera reduces the risk of subsequently becoming ill both for children under 5 and older persons (Ali 2012). In an endemic setting as Dhaka, a higher immunity can generally be expected among adults. Our model does not take immunity into account.

Large differences have been found between the slum/poor population and the middle class in Paltan and Razarbag which are both mixed population areas. For children the average cholera risk was 19 to 109 times higher in the poor/slum areas than in the middle-class areas, and for adults the average risk was $>140$ times higher. Diahrreal infections are known to be related to socio-economic factors. Of diahrreal patients from the poor Mirpur area in Dhaka (2008 - 2010) 89\% lived in low-income housing 
and only $8 \%$ in independent houses or high income residential areas (Chowdury, 2011), and Colombara (2013) found a 50\% higher cholera risk for children under 5 years living in slum in Dhaka.

\section{Conclusions}

In the present study, a novel modelling approach has been developed and demonstrated for Dhaka City.

The approach defines a consistent framework for analyses of the health risks associated with direct contact with urban flood water. The framework consists of a hydrodynamic model in combination with an advection-dispersion model, providing input to a quantitative microbial risk assessment. Based on computations of the health risk at three a priori selected locations, it was found that direct environmental exposure during flooding results in an estimated average cholera risk ranging from 5.2 . $10^{-5}$ to $2.2 \cdot 10^{-3}$, with small children in the slum areas having the highest risk. Hence, the computed health risk is in agreement with the overall incidence of severe cholera in Dhaka City, which in 2010 was estimated to be approximately 280 per 100.000 . Contact with polluted flood water is therefore a plausible route of primary transmission of cholera and may partly explain the fall cholera peak in Dhaka. However, the absolute risk estimates should be interpreted with caution, due to a high uncertainty. The presented framework will be updated when new knowledge and data become available in order to reduce the uncertainties. The framework may be extended to include other important waterborne pathogens, for which credible dose-response relations have been published, such as E. coli (ETEC), rotavirus and Salmonella enterica typhi.

An extension of the risk analysis to cover the entire flooded area and combine the estimated risks with population data will provide an estimation of the geographical distribution of the burden of cholera related to direct contact with flood water. This data can then be used to identify the most critical points

for intervention and control of cholera. If other significant waterborne pathogens are included in the

This article is protected by copyright. All rights reserved. 
assessment as well, the total burden of disease (expressed as DALY) from direct contact with flood water can be mapped and applied for identifying the most critical points for intervention and control of diarrheal diseases.

This study does not analyse the risk of cholera from exposure via drinking water contaminated during flooding events. A study of the relation between flooding and drinking water quality will be necessary to implement the most cost-effective interventions, taking both exposure via drinking water and direct exposure to flood water into account.

\section{Acknowledgement}

Research on the CORFU (Collaborative research on flood resilience in urban areas) project was funded by the European Commission through Framework Programme 7, Grant Number 244047, and by the Danish Ministry of Higher Education and Science through the DHI performance contract with the Danish Agency for Science, Technology and Innovation, 2013-2015. Dr. Zahid Hayat Mahmud and the team at Environmental Microbiology Laboratory, Centre for Food and Waterborne Diseases, International Centre for Diarrhoeal Disease Research, Bangladesh (ICDDR,B) are acknowledged for their magnificent analytical work. The authors would like to thank Dr. Heleen de Man, Institute for Risk Assessment Sciences, Utrecht University, The Netherlands for providing flood exposure data. 


\section{References}

AKANDA, A. S., JUTLA, A. S., ISLAM, S. 2009. Dual peak cholera transmission in Bengal Delta: A hydro climatological explanation. Geophysical Research Letters. 36, 19, L19401. DOI: 10.1029/2009GL039312.

AKANDA, A.S., JUTLA, A.S., ALAM, M., DE MAGNY, G.C., SIDDIQUE, A. K., SACK, R.B., HUQ, A., COLWELL, R.R., ISLAM, S. 2011. Hydroclimatic influences on seasonal and spatial cholera transmission cycles: Implications for public health intervention in the Bengal Delta. Water Res. Research, 47(5) WOOH07, doi:10.1029/2010WR009914.

Akanda, A.S., Jutla, A.S., Gute, D.M., Sack, R.B., Alam, M., Huq, A., Colwell, R.R., Islam, S.2013.

Population vulnerability to biannual cholera outbreaks and associated macro-scale drivers in the Bengal Delta. Am. J. Trop. Med. Hyg. 89(5), pp 950-959. doi: 10.4269/ajtmh.12-0492.

ALAM, M., SULTANA, M., NAIR, G. B., SACK, R. B., SACK, D. A., SIDDIQUE, A. K., ALI, A., HUQ, A., COLWELL, R. R. (2006) Toxigenic Vibrio cholerae in the aquatic environment of Mathbaria, Bangladesh. Appl. Environ. Microbiol. 72, 4, 2849-55. DOI: 10.1128/AEM.72.4.2849-2855.2006.

ALAM, M., ISLAM, A., BHUIYAN, N. A., RAHIM, N., HOSSAIN, A., KHAN, G. Y., AHMED, D., WATANABE, H., IZUMIYA, H., FARUQUE, A. S., AKANDA, A. S., ISLAM, S., SACK, R. B., HUQ, A., COLWELL, R. R., AND CRAVIOTO, A. (2011) Clonal transmission, dual peak, and off-season cholera in Bangladesh. Infection Ecology and Epidemiology, 1., 7273 - DOI: 10.3402/iee.v1i0.7273.

ALI, M., LOPEZ, A.L., YOU, Y.A., KIM, Y.E., SAH, B., MASKERY, B., and CLEMENS, J. (2012) The global burden of cholera. Bull World Health Organ, 90, pp. 209-218. doi:10.2471/BLT.11.093427. 
ANDERSEN, S., ERICHSEN, A., MARK, O., ALBRECHTSEN. H-J. (2013) Effects of a 20 year rain event: quantitative microbial risk assessment of a case of contaminated bathing water in Copenhagen, Denmark. Journal of Water and Health. Vol. 11.4 - pp. 636-646.

ANDERSEN, H.S., TAMAŠAUSKAS, H., and MARK, O. (2004) The Full Urban Water Cycle - Modeling with MIKE URBAN. 7th Urban Drainage Modelling, Dresden, Germany.

APHA (American Public Health Association) (1998) Standard Methods for the Examination of Water and Wastewater. 20th edition. American Public Health Association/American Water Works Association/Water Environment Federation, Washington, District of Columbia.

BLACK, R.E., LEVINE, M.M., CLEMENTS, M.L., YOUNG, C.R., SVENNERHOLM, A.M. and HOLMGREN, J. (1987) Protective efficacy in humans of killed whole-vibrio oral cholera vaccine with and without the B subunit of cholera toxin. Infect Immun, 55, 5, pp. 1116-1120.

BORROTO, R.J. (1997) Ecology of Vibrio cholerae serogroup 01 in aquatic environments. Rev Panam Salud Publica/Pan Am J Public Health, 2(5), pp.328-333.

BUI, A., REYES, F., FOSTER, J., GENTRY, J., LIMAYEM, A., LOPEZ, J., and STOTT, R (2011) Cholera in Haiti. QMRA case study, QMRA Workshop, August 2011, University of Michigan, US. http://qmrawiki.msu.edu, accessed 31 Jan 2014.

CAMRA (2014) Quantitative Microbial Risk Assessment. QMRA, Wiki. http://qmrawiki.msu.edu/

CARR, R., SMITH, G. (2007) Linking 2D and pipe hydraulic models at fine spatial scales. Water Practice \& Technology. 2(2) doi10.2166/wpt.2007.0038. 
CASH, R.A., MUSIC, S.I., LIBONATI, J.P., SNYDER, M.J., WENZEL, R.P. and HORNICK R.B. (1974) Response of Man to Infection with Vibrio cholerae. I. Clinical, Serologic, and Bacteriologic Responses to a Known Inoculum. The Journal of Infectious Diseases, 129, 1, pp. 45-52.

CHOWDHURY, F., RAHMAN, M.A., BEGUM, Y.A., KHAN, A.I., FARUQUE, A.S.G. et al. (2011) Impact of Rapid Urbanization on the Rates of Infection by Vibrio cholerae $\mathrm{O}$ and Enterotoxigenic Escherichia coli in Dhaka, Bangladesh. PLoS Negl Trop Dis, 5(4): e999. doi:10.1371/journal.pntd.0000999.

COLOMBARA, D.V., COWGILL, K.D., FARUQUE, A.S.G. (2013) Risk Factors for Severe Cholera among Children under Five in Rural and Urban Bangladesh, 2000-2008: A Hospital-Based Surveillance Study. PLOS ONE, 8(1): e54395. doi:10.1371/journal.pone.0054395.

COLWELL, R.R. (2005) Global Microbial Ecology of Vibrio cholerae. In: Eds. Belkin and Colwell. Oceans and Health: Pathogens in the Marine Environment. Springer, New York.

DEEN, J.L., VON SEIDLEIN, L., SUR, D., AGTINI, M., LUCAS, M.E.S. et al. (2008) The High Burden of Cholera in Children: Comparison of Incidence from Endemic Areas in Asia and Africa. PLoS Negl Trop Dis, 2(2): e173. doi:10.1371/journal.pntd.0000173.

DIZON, J.J., FUKUMI, H., BARUA, D., VALERA, J., JAYME, F., GOMEZ, F., YAMAMOTO, S.-I, WAKE, A., GOMEZ, C.Z., TAKAHIRA, Y., PARAAN, A., ROLDA, L., ALVERO, M., ABOU-GAREEB, A.H., KOBARI, K., and Azurin, J.C. (1967) Studies on cholera carriers. Bull World Health Organ, 37(5): pp. 737-743.

DOREVITCH, S., PANTHI, S., HUANG, Y., LI, H., MICHALEK, A.M., PRATAP, P., WROBLEWSKI, M., LIU, L., SCHEFF, P.A., Li. (2011) Water ingestion during water recreation. Water Res., 45(5):2020-8. 
FAO (2005). Risk assessment of choleragenic Vibrio cholerae 01 and 0139 in warm water shrimp for international trade: interpretative summary and technical report. Microbiological risk assessment series. Vol 9. URL: http://apps.who.int/iris/handle/10665/43388.

FEACHEM, R. G., BRADLEY, D.J., GARELICK, H., and MARA, D.D (1983) Sanitation and disease: health aspects of excreta and wastewater management. World Bank Studies in Water Supply and Sanitation 3.

GARSDAL, H., Mark, O., DØRGE, J., and JEPSEN, S.E. (1995) MOUSETRAP: Modelling of water quality processes and interaction of sediments and pollutants in sewers. Water Science \& Technology, vol. 31, pp. 33-41, 1995.

http://econ.worldbank.org/external/default/main?pagePK=64165259\&theSitePK=469372\&piPK=641654 21\&menuPK=64166093\&entityID=000178830_98101911180473

HAAS, C.N., ROSE, J.B., and GERBA, C.P. (1999) Quantitative microbial risk assessment. John Wiley and Sons Inc., New York. ISBN 0-471-18397-0.

HARA-KUDO, Y., NISHINA, T., NAKAGAWA, H., KONUMA, H., HASEGAWA, J., and KUMAGAI, S. (2001) An improved detection method for Vibrio parahaemolyticus in seafood. Appl. Environ. Microbiol., 67, pp.5819-5823.

HARTNACK, J.N., ENGGROB, H.G. and RUNG $\varnothing$, M. (2009) 2D overland flow modelling using fine scale DEM with manageable runtimes. Flood Risk Management: Research and Practice. Samuels et al. (eds), Taylor \& Francis Group, London, ISBN 978-0-415-48507-4.

HASHIZUME, M., WAGATSUMA, Y., FARUQUE, A.S.G., HAYASHI, T., HUNTER, P.R., ARMSTRONG, B., and SACK, D.A. (2008). Factors determining vulnerability to diarrhoea during and after severe floods in Bangladesh. J Water and Health, 06, 3, pp. 323-332.

This article is protected by copyright. All rights reserved. 
HUQ, A., COLWELL, R.R., RAHMAN, R., ALI, A., CHOWDHURY, M.A.R., PARVEEN, S., SACK, D.A., RUSSEKCOHEN, E. 1999. Detection of Vibrio cholerae $\mathrm{O} 1$ in the aquatic environment by fluorescent-monoclonal antibody and culture methods. Appl. Environ. Microbiol. 56(8), pp. 2370-2373.

ICDDR,B. (2004) Surveillance update. Health and Science Bulletin, Vol. 2, No. 4, December 2004.

ICDDR,B. (2011) Estimated incidence of cholera in the catchment area of two diarrhoeal diseases hospitals in Dhaka City. Health and Science Bulletin, Vol. 9, No. 4, December 2011.

INNOVYZE (2013). InfoWorks ICM - Integrated Catchment Modeling [online]. Available from: http://www.innovyze.com/products/infoworks_icm/ [Accessed 2nd Oct. 2013].

ISLAM, M.S., ALAM, M.J., and KHAN, S.I. (1995) Occurance and distribution of culturable Vibrio cholera $\mathrm{O} 1$ in aquatic environment of Bangladesh. Int. J. Environ, Studies 47 (3), pp. 217-223.

ISLAM, M.A., SAKAKIBARA, H., KARIM, M.R., SEKINE, M., and MAHMUD, Z.H. (2011) Bacteriological assessment of drinking water supply options in coastal areas of Bangladesh. Journal of Water and Health, 2011; 9(2): pp. 415-42.

ISO 7899-2:2000. Water quality -- Detection and enumeration of intestinal enterococci -- Part 2: Membrane filtration method.

JUtla, A., Whitcombe, E., hASAN, N., HALEY, B., AKANDA, A., HUQ, A., AlAM, M., SACK, R. B., COLWELL, R. (2013). Environmental factors influencing epidemic cholera. Am. J. Trop. Med. Hyg. 89,3, 597-607. DOI: 10.4269/ajtmh.12-0721.

KATUKIZA, A.Y., RONTELTAP, M., VAN DER STEEN, P., FOPPEN, J.W., and LENS, P.N. (2013) Quantification of microbial risks to human health caused by waterborne viruses and bacteria in an urban slum. J Appl Microbiol., 2013 Oct 15. doi: 10.1111/jam.12368.

This article is protected by copyright. All rights reserved. 
KELLY, M.T., HICKMAN-BRENNER, F.W., and FARMER III, J.J. (1992) Vibrio. In: Manual of clinical microbiology (Balows, A., Hausler Jr., W.J., Hermann, K.L., Isenberg, H.D., and Shadomy, H.J. eds). 5th edition. ASM Press, Washington, District of Columbia, pp. 384-395.

KOELLE, K., RODO, X., PASCUAL, M., YUNUS, M., and MOSTAFA, G. (2005) Refractory periods and climate forcing in cholera dynamics. Nature, 436: pp. 696-700.

LABITE, H., LUNANI, I., VAN DER STEEN, P., VAIRAVAMOORTHY, K., DRECHSEL, P., and LENS, P. (2010) Quantitative Microbial Risk Analysis to evaluate health effects of interventions in the urban water system of Accra, Ghana. J Water Health, 2010 Sep; 8(3): pp. 417-30. doi: 10.2166/wh.2010.021.

LEVINE, M.M., BLACK, R.E., CLEMENTS, M.L., NALIN, D.R., CISNEROS, L., and FINKELSTEIN, R.A. (1981). Volunteer studies in development of vaccines against cholera and enterotoxigenic Escherichia coli: a review, p. 443-459. In Acute enteric infections in children. New prospects for treatment and prevention (Holme, T., Holmgren, J., Merson, M.H., and Mollby, R. (ed.). Elsevier/North-Holland Biomedical Press, Amsterdam.

LEVINE, M.M., BLACK, R.E., CLEMANTS, M.L., LANATA, C., SEARS, S., HONDA, T., et al. (1984) Evaluation in Humans of Attenuated Vibrio cholerae El Tor Ogawa Strain Texas Star-SR as a Live Oral Vaccine. Infection and Immunity, 43, pp. 515-522.

LEVINE, M.M., KAPER, J.B., HERRINGTON, D., LOSONSKY, G., MORRIS, J.G., CLEMENTS, M.L., BLACK, R.E., TALL, B. and HALL, R. (1988) Volunteer studies of deletion mutants of Vibrio cholerae 01 prepared by recombinant techniques. Infect. Immun. January 56, 1, pp. 161-167.

LIPP, E.K., HUQ, A., and COLWELL, R.R. (2002) Effects of global climate on infectious disease: the cholera model. Clin Microbiol Rev., 2002 Oct., 15(4): pp. 757-70.

This article is protected by copyright. All rights reserved. 
LONGINI, I.M. Jr, YUNUS, M., ZAMAN, K., SIDDIQUE, A.K., SACK, R.B., and NIZAM, A. (2002) Epidemic and endemic cholera trends over a 33-year period in Bangladesh. J Infect Dis., 15; 186(2): pp. 246-51.

LOUIS, V. R., RUSSEK-COHEN, E., CHOOPUN, N., RIVERA, I. N. G., GANGLE, B., JIANG, S. C., RUBIN, A., PATZ, J. A., HUQ, A., AND COLWELL, R. R. 2003. Predictability of Vibrio cholerae in Chesapeake Bay. Appl. Environ, Microbiol. 69, 5, 2773-2785. DOI: 10.1128/aem.69.5.2773-2785.2003.

DE MAN, H., VAN DEN BERG, H.H.J.L., LEENEN, E.J.T.M., SCHIJVEN, J.F., SCHETS, F.M., VAN DER VLIET, J.C., VAN KNAPEN, F., and DE RODA HUSMAN, A.M. (2014) Quantitative assessment of infection risk from exposure to waterborne pathogens in urban floodwater. Water Research, 48, 1, pp. 90-99.

MARK, O., HERNEBRING, C., MAGNUSSON, P. (1998) Optimisation and control of the inflow to a wastewater treatment plant using integrated modelling tools. Water Science and Technology, vol. 37, no. 1 , pp. $347-354,1998$.

MARK, O., APPELGREN, C., KOSIR, M. (1996) Water quality modelling for the Ljubljana master plan. ICUSD '96, Hannover, Germany, 9-13 September 1996.

MARK, O., WEESAKUL, S., APIRUMANEKUL, C., BOONYA AROONNET, S., and DJORDJEVIĆ. S. (2004) Potential and limitations of 1-D modelling of urban flooding. Journal of Hydrology, 2004.

MARK, O. and DJORDJEVIĆ, S. (2006) While waiting for the next flood in your city.... Proceedings of 7th International Conference on Hydrolnformatics - Nice, France. Pp. 252-265.

MILLER, C.J., FEACHEM, R.G., DRASAR, B.S. 1985. Cholera epidemiology in developed and developing countries: new thoughts on transmission, seasonality, and control. The Lancet. 325,8423, 261-263.

RABBANI, G. H., GREENOUGH III, W. B. 1999. Food as a vehicle of transmission of cholera. J. Diarrhoeal Diseases Research, 17(1), pp. $1-9$. 
RAMAMURTHY, T. AND SHARMA, N. C. 2014. Cholera outbreaks in India. Current Topics in Microbiology and Immunology. 379, 49-85.

REINER, R.C., Jr., KING, A.A., EMCH, M., YUNUS, M., FARUQUE, A.S.G., and PASCUAL, M. (2012) Highly localized sensitivity to climate forcing drives endemic cholera in a megacity. PNAS, 109 (6), pp. 20332036.

RUBINATO, M., SHUCKSMITH, J., SAUL, A.J., SHEPHERD, W. (2013) Comparison between InfoWorks hydraulic results and a physical model of an Urban drainage system. Wat. Sci. Tech. 68(2), pp 372-379.

RUIZ-MORENO, D., PASCUAL, M., EMCH, M., YUNUS, M. 2010. Spatial clustering in the spatio-temporal dynamics of endemic cholera. BMC infectious diseases. 10:51. Doi: 10.1186/1471-2334-10-51.

SCHETS, F.M., SCHIJVEN, J.F., and DE RODA HUSMAN, A.M. (2011) Exposure assessment for swimmers in bathing waters and swimming pools. Water Research, 45, 7, pp. 2392-2400.

SCHWARTZ, B.S., HARRIS, J.B., KHAN, A.I., LAROCQUE, R.C., SACK, D.A., MALEK, M.A., FARUQUE, A.S., QADRI, F., CALDERWOOD, S.B., LUBY, S.P., and RYAN, E.T. (2006) Diarrheal epidemics in Dhaka, Bangladesh, during three consecutive floods: 1988, 1998, and 2004. Am J Trop Med Hyg., 74,6, pp. 106773.

SCHMITT, T.G., THOMAS, M., ETTRICH, N. 2004. Analysis and modeling of flooding in urban drainage systems. J. Hydrology. 299(3-4), pp 300-311.

SUR, D., DEEN, J.L., MANNA, B., NIYOGI, S.K., DEB, A.K., KANUNGO, S., SARKAR, B.L., KIM, D.R., DANOVARO-HOLLIDAY, M.C., HOLLIDAY, K., GUPTA, V.K., ALI, M., VON SEIDLEIN, L.J., CLEMENS, D., and BHATTACHARYA, S.K. (2005) The burden of cholera in the slums of Kolkata, India: data from a prospective, community based study. Arch Dis Child, 90: pp. 1175-1181. doi: 10.1136/adc.2004.071316. 
WHO (2013) Progress on Drinking water and Sanitation. 2013 update. World Health Organization and UNICEF. http://apps.who.int/iris/bitstream/10665/81245/1/9789241505390_eng.pdf Accessed 1st. May 2014.
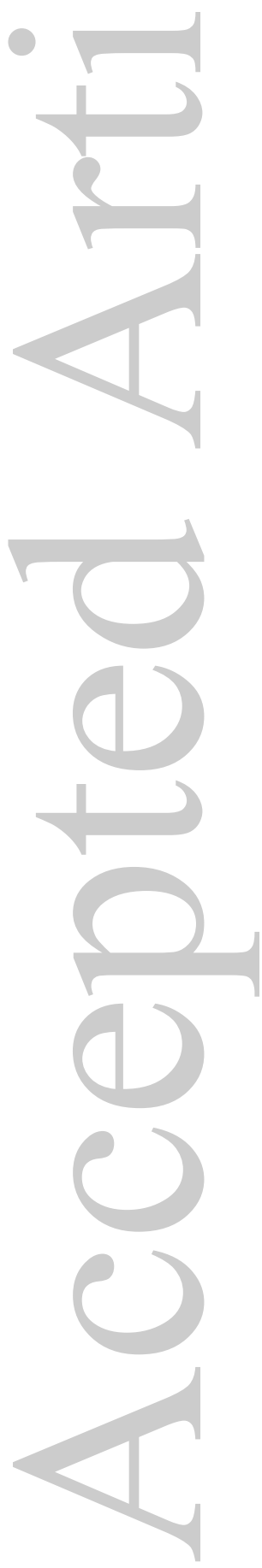

This article is protected by copyright. All rights reserved. 